\title{
The "Blood Libel" and the Spectator's Eye in Norwich and Toronto
}

\section{DAVID TOWNSEND}

\begin{abstract}
David Townsend (townsend@chass.utoronto.ca) is Associate Professor of Medieval Studies and English as well as Director of the Sexual Diversity Studies Program at the University of Toronto. He is coeditor, with Andrew Taylor, of The Tongue of the Fathers: Gender and Ideology in TwelfthCentury Latin. This essay grows out of his larger interest in the coexistence of conflicting religious discourses in medieval Norwich. It assesses the similarities in and differences between the oppressive strategies around the murder of innocent children by Jews and homosexual men, respectively.
\end{abstract}

A gregarious, plucky twelve-year-old boy appears regularly on the streets, working as he can to supplement the resources of his poor but loving family. His routine puts him in contact with unsavoury elements, against whom his innocence and naiveté are a poor match. A stranger meets him and shortly thereafter lures him to a private place with promises of money to be earned. There the ensnarer and his confederates abuse the boy horribly and eventually kill him in an obsessive, orgiastic frenzy. They dispose of the body, but with insufficient stealth. The corpse is subsequently discovered, and the full horrors of what happened are reconstructed with the assistance of a witness to the tortures the boy endured. Clear traces on the victim's body supplement that testimony to his sufferings. Testimony 


\section{2 / Townsend}

and deduction meet in a narrative that synthesizes the available details, but which also bears, in its repetitions and its speculative tone, the marks of its piecemeal and reconstructive origins. Despite its gaps, the tale apprises an appalled public of the outrage perpetrated by outsiders in their midst. The demands of popular opinion for just retribution are ultimately both heeded and contained by the apparatus of the state. But the child's memory lives on and alerts the public to the dangers of moral contagion presented by the class of social parasites who, if not the boy's actual murderers, are certainly by their very presence the fomenters of all such crimes against the innocent young. The awful but ultimately saving truth is recognized: the boy's death has galvanized the social body into a necessary state of vigilance. His innocent life, it can now be observed, is the price paid to cleanse the social and spiritual life of the community. The child's interment offers a focus in shared ritual for the cleansing recognition of the purity he preserved even unto death, but at the same time it consolidates the memory of the unspeakable and unavenged act that society must never forget.

I have been describing the July 1977 murder of Emanuel Jaques, a shoeshine boy in downtown Toronto, and its aftermath, much as it was described in the voluminous newspaper coverage it received in the weeks after his death and again during the February 1978 trial of four men charged with and subsequently convicted of the crime. But I have also been describing the martyrdom of little William of Norwich in 1144, much as it was described by Thomas of Monmouth, who, beginning in 1149, five years after the boy's death, recorded for posterity the story of his alleged murder at the hands of the Norwich Jews (Jessop and James).

Thomas's biography of William stands not only as the most substantial single hagiographical source of the "blood libel"-the repeated charge that Jews ritually murdered Christian children around Passover-but as its actual point of origin in the West, as Gavin Langmuir has shown (1984). Langmuir and others have intensively scrutinized the text for its witness to conditions in 
Norwich at the time of its writing, between 1149 and 1172-73. ${ }^{1}$ Langmuir, as a historian, demonstrates great concern not so much to establish what actually happened, and did not happen, to William, as to determine who first invented the charge of ritual murder by crucifixion. His conclusion is that it is the invention of the hagiographer Thomas himself. Langmuir acknowledges the deadly power the myth has had in subsequent European culture, at the same time that he points out that Thomas was himself not primarily motivated by hatred of Jews. Mercifully, the text of Thomas of Monmouth exists only in a single copy. But the blood libel narrative that he created spread throughout Europe, staining the lips of Chaucer's Prioress along its path; over the centuries it has cost thousands, if not millions, of lives. Similarly, it is the use to which the dead Emanuel Jaques was put by the political and journalistic establishment of Ontario that concerns me here.

As I wrote the précis of the opening paragraph, I found myself running a rapid relay of memory between Thomas's text and a file of clippings on the murder trial. ${ }^{2}$ How many narrative elements could I include in my initial summary of events without reducing one story to a trope of the other? Could I cast a sentence representing the murder(s) that ventriloquized the lurid sensationalism of both accounts and at the same time did not tip the reference in the exclusive direction of either sociopathic sexual license (the Jaques murder) or imputed religious fanaticism (William's martyrdom)? Could I allude to the funeral of Emanuel Jaques at a Portuguese Catholic church in Toronto in language that did not distort the circumstances of the translation of William's body from the woods outside Norwich, where it was first discovered, to the monks' cemetery at the cathedral? Or distort, for that matter, the fact that in William's case I'm not dealing with a single interment, but with an almost ghoulish obsession, even by medieval Christian standards, with repeated translation ceremonies (four in a decade)? Could I

${ }^{1}$ See Langmuir for his revision of M. R. James's earlier dating of the entire text to $1172-73(1984,838-40)$.

2 All citations from periodicals are drawn from the holdings of daily press clippings in the Canadian Lesbian and Gay Archives in Toronto, whose staff I wish to thank for their help. 


\section{4 / Townsend}

mimic the platitudinous metamorphosis of innocent suffering into salvific necessity, without falling off the line into the secularized moralism of WASP Toronto journalism, on the one hand, or into the more narrowly hagiographical tropes of imitatio Christi, on the other? Could I, in short, evoke representations of the 'degeneracy' of both gay men and Jews, without collapsing one into the other?

And moreover, why would I want to indulge in this exercise? Part of the answer to that is, inevitably, a matter of personal history. I first moved to Toronto in 1977, a few weeks after the Jaques murder, when, in my early twenties, I was still far from entirely out of the closet. A few months earlier, Anita Bryant had 'saved' the children of Dade County, Florida from the prospect of growing up in a society which accorded equal protection under the law on grounds of sexual orientation. ${ }^{3}$ In Toronto, the first major city in which I had ever lived, the daily press coverage of the killing and trial offered the murderers of Emanuel Jaques as the most pervasively and powerfully represented of all homosexual men. At the time, I perceived the discourse of those representations as almost seamlessly monologic.

Such perceptions were of course skewed by the terror that discourse held for me. Going back to review the documents a generation later, I remember the terror and despair, but it is also clear that the presentation was as characterized by rupture and internal dissent as is any such apparatus of ideology: it is due to those ruptures and their later valorizations that much has changed in the Canadian politics of sexual orientation over the last two decades (Rayside 105-211). At the time of the murder, the Ontario Human Rights Commission was in fact recommending that Ontario incorporate sexual orientation as a protected category under its human rights code. (The actual passage of that amendment would wait until the mid 1980s, when a Liberal minority government was pushed toward the legislation by the New Democrat opposition with which the government had entered into a coalitional agreement

${ }^{3}$ The referendum, held on June 7, 1977, repealed by a margin of 69 to 31 per cent a Dade County ordinance which had prohibited discrimination on the basis of "affectional or sexual preference" in the areas of housing, public accommodations, and employment (Hamburg 1). 
[Rayside 142-43].) But the reportage of dissenting voices to the side, the press's obsessive repetitions of the details of the boy's multiple rape, and of his assailants' repeated botched attempts to kill him, imparted a naturalized energy to a plethora of outraged voices. Those voices called for a clean sweep of the human trash downtown (Grass) and rejected the statutory protection of lifestyles that led to such crimes (Davidson; Hoy; Ross; Shulman; Worthington; "Not so "Gay"). The totalizing objectifications of homosexuality and of homosexuals made it clear that I was part of the human trash that needed sweeping up.

The fact is that for the past twenty years, my reading of the blood libel "saints' lives" of murdered little Christian boys has necessarily been a polyphonic one, imbued with intertextual associations not because of the allure of their postmodern vogue, but because those associations are burned into my consciousness. I read the text of Thomas of Monmouth, that opportunistic scum of the twelfth century, much as I read the 1977 and 1978 Toronto Sun columns of Claire Hoy. ${ }^{4}$ I am not particularly interested in doing justice to the Weltanschauung of either.

Of course, I am not the only gay man to make such connections between anti-Semitism and homophobia. In bathhouse raids one Thursday night in Toronto in early February 1981, 150 Toronto police officers swooped down simultaneously with crowbars and sledgehammers on five establishments and arrested some 286 gay men. Immediately thereafter, a local gay activist compared the

${ }^{4}$ Some of the choicest examples of Hoy's homophobic vitriol were in fact generated not by the story of the Jaques murder, but by the December 1977 raids on the offices of The Body Politic, a radical gay liberation journal published in Toronto. But in the peroration of the August 10, 1977 editorial already cited, Hoy can be seen moving toward a wholesale appropriation of homophobia as the substance of his professional output: "They complain they haven't been getting the press they deserve. I agree. Until recently, the coverage they got was far too soft, accepting their line about how wonderful gay life is when in fact it's not. It's unnatural and sick. Period. They want to institutionalize it, to have it taught in the schools, and thanks to lunkhead organizations like the Ontario Human Rights Commission they appeared to be making progress. But not now. Not with public sentiment swinging against them. There's no way [Ontario premier] Billy Davis and his bunch are going to touch the OHRC recommendations giving gays all sorts of rights and privileges they think they deserve." 


\section{6 / Townsend}

operation to the Kristalnacht. ${ }^{5}$ I clearly recall a placard at one of the demonstrations after the raid, though I cannot find any documentation of it now, that read "We are the new Jews." The connection is hardly surprising, given the adoption of the pink triangle from the Nazi death camps as probably the most widespread symbol of the queer liberation movement. To be sure, there are substantial dangers in an untheorized assertion of such connections. Pragmatically, such aphorisms can easily trigger - have repeatedly triggered - divisive games of "More oppressed than thou." And the elision of profound historical differences between the oppressions of Jews and of gay men does nothing to further a politically and culturally useful analysis of either.

The fact of my hermeneutic predicament remains, however, and it is clear from the connections drawn by other gay men between their oppression and anti-Semitism that I am not alone at my peculiar interpretive intersection. ${ }^{7}$ That my intersection is large

5 The raids took place on February 5 and were followed immediately by protests, which continued with mounting attendance and escalating possibilities of violence through the summer. The protests focused on the trials of the men charged as "found-ins" and "keepers," and on the anniversary of the raids. Coverage of the first of the demonstrations and retrospective coverage of the raids themselves was carried by various regional editions of the Globe and Mail on February 7, 1981 (Mulgrew). The comparison to the Kristalnacht was reported elsewhere in the Globe and Mail on the same day as it was being made by George Hislop, a Toronto gay activist (and bathouse proprietor). One sign carried in the February 7 protest read "Liars, bigots, Nazis: Toronto cops" (Mulgrew, "1,500 demonstrators," Toronto edition). Comprehensive coverage of the raids and their aftermath appeared in The Body Politic, beginning with the March 1981 issue. That coverage included a more direct quotation of George Hislop's remarks: "It was midnight, February 6-just 24 hours after what George Hislop has called the gay equivalent of the "Crystal Night in Nazi Germany - when the Jews found out where they were really at"' (Hannon 9). (Kristalnacht - usually translated as "The Night of Broken Glass" - is the name given to the anti-Jewish pogrom organized by the Nazis in Germany and Austria on the night of November 9-10, 1938. For specifics, see the Museum of Tolerance's informative webpage at $<\mathrm{http}: / / \mathrm{www}$.wiesenthal.com $/ \mathrm{mot} / \mathrm{moths}$. htm\#kristalnacht>.)

${ }^{6}$ Hislop's comment, for example, produced an outraged refutation of any similarities between the circumstances of German Jews and Canadian gays (Jonas).

${ }^{7}$ In a more directly academic context, John Boswell alludes to the historical parallels between the social status of gays and of Jews and immediately qualifies those parallels (16-17). Boswell's observation leaves me with the impression that he, too, 
enough to accommodate others as well is what $I$ wished to demonstrate with my initial fence-sitting simultaneous paraphrase of the two murder stories. And my project in this essay has to do, if not with faith seeking understanding, then with the intuitions of lived experience seeking theory. That search involves two overlapping movements. The first might be thought of as the 'what' of the two narratives' rhetoric - a delineation of the unsettling structural resemblances between them. The second might be seen as the 'how' and 'why' of their rhetoric - a consideration of the cultural work, in radically different milieus, that those parallel narrative trajectories appear to perform.

In pursuing the first of those movements, I confine myself, unlike Langmuir, to issues of discursive formations. Somebody murdered a boy named William and left the body in Thorpe Wood just before Easter of 1144. The four men accused and convicted of Emanuel's murder certainly killed him above a body-rub parlor on Yonge Street in the summer of 1977. But I want to steer clear of the events themselves and their status as facts. I want to focus, rather, on the cultural power of the narratives constructed around the putative givens of the events. That power has been as substantial as it is insidious.

In pursuing the second of my aims, I spend more time than does Langmuir on the 'how' as opposed to the 'what' of the narrative qua narrative. Langmuir adumbrates this question, when he remarks on the unusually scopic quality of the medieval text's rhetoric: "We observe William's disappearance with a stranger who takes him to a Jew's house, we watch him being tortured and crucified by Jews, we listen to the murderers talking among themselves about how to dispose of the body, and we are told how they did dispose of it and how it was found" $(1984,828)$. But this comment aside, Langmuir passes fairly lightly over the pragmatics of Thomas of Monmouth's rhetoric. It is with such considerations in mind that I read Thomas's text against the newspaper coverage of the Jaques trial. How does each text situate the reader in relation to 


\section{8 / Townsend}

the chimerical perpetrators of the murder? What relation does the all-seeing eye that witnesses William's, or Emanuel's, torture behind closed doors bear toward the violence the text represents? Is that relation one of passive observation, or of active though vicarious participation in the violence that the text ostensibly deplores? And how, moreover, do the public rituals recounted in, and as, the history of the cult's development provide mechanisms whereby such vicarious experiences can be articulated in a socially visible form?

Some readers might entertain doubts about the commensurability of a medieval saint's life and a file of newspaper clippings. I read the collected coverage of the Jaques trial as a single and very vaguely bounded whole, a text that bled out into the Toronto communities that consumed it and absorbed again the discursive energies those communities fed back into it. If reading such a ragtag file of fragments as a whole is problematic, one should keep in mind that the wholeness of Thomas of Monmouth's text, for its part, is also problematic. Thomas composed it over a period of more than twenty years. The first book is datable to 1149 , Books 2-6 to $1154-55$, and Book 7 to $1172-73$. Book 2 is largely a pointed response to unnamed opponents of William's claims to sanctity. Much of the energy that feeds Thomas's vivid imaginings of childhood innocence and Jewish guilt must surely have been absorbed into the text from the oral circulations of Norwich in the years before Thomas's arrival there in the late 1140s. The impetus for the central five books is clearly drawn in large part from the reception of the text's first book. The intertextual vagaries that blur the boundaries of Thomas's text are more submerged, but no less problematic, than those surrounding the coverage of the Jaques murder and trial, and it is with this in mind that I read the two narratives as comparable documents.

The two stories' shared elements begin with the memories of characteristic good cheer projected back onto the lives of both boys. News of the discovery of Emanuel Jaques's body first broke on August 1, 1977, four days after the boy's disappearance from the Yonge Street "sin strip" opposite a vast, newly erected downtown shopping concourse, the Eaton Centre. The boy had last been seen, the front page story in the Toronto Star said, "walking away from Yonge St. with a man who offered to pay him $\$ 35$ an hour to help 
move camera equipment. He had been polishing shoes on the strip for about a month with his brother ... and a friend ... The brothers used to hand over their \$35-a-night earnings to their parents. About 5.30 p.m. last Thursday a man dressed in overalls talked to the boys, bought them hamburgers and asked Manuel (sic) if he would like to work with him ... 'let me earn the money, let me earn the money,' Manuel cried" (Gwyn Thomas).

Several interesting parallels emerge with the story of William even at this early stage in the ongoing construction of the Jaques narrative. Emanuel's innocence, soon to become a trope of explicitly hagiographical force, is already adumbrated in the explanation that the enterprising young brothers hand their earnings over to their parents every night: Emanuel's rovings in the heart of the downtown core are thus drawn into the cohesive circle of his family life. The trope of Emanuel's innocence builds rapidly in the coverage of the case. The next day in the Star, a page 2 article begins, "Emanuel Jaques was an outgoing 12-year-old who loved to make friends and who trusted everyone - and that led him to his death" (Bullock, Dalby, and Norris). The same piece adds later that everyone interviewed agreed that the boy's lack of street smarts had rendered him vulnerable. This innocence was extended, moreover, to Emanuel's entire Portuguese immigrant family: the article suggests they remained unaware - after several years of living in a downtown public housing project - of the true nature of the place they by all accounts allowed a twelve-year-old to roam unsupervised for hours at a time. An interview with the mother of Emanuel's friend and fellow shoeshine boy Shane McLean was reported as follows:

Mrs. McLean asked the Jaques' 17-year-old daughter, Valdemira, if her mother understood about homosexuals and the possible danger her missing son might be in.

"She tried to tell her mother about it in Portuguese, and she didn't understand. She'd never heard of it, didn't know what the daughter was saying. That explains how Emanuel knew so little. One of the first things Shane said to me when he explained about the man taking Emanuel away was: 'Mom, the guy was queer'." (Bullock et al.)

The same article records testimonies by family and neighbors to the 


\section{0 / Townsend}

cheerful obedience of a child who did "all kinds of chores, but never asked for money." The same day, the tabloid Toronto Sun began its article with a further paean to his cheerful and family-centered obedience (Scanlon).

The parallels with the representations of little William's precocious virtues are clear: they amount to a shared hagiographical topos. Though of course more secularized - unlike William, for example, Emanuel does not fast Mondays, Wednesdays, and Fridays - Emanuel's virtues are equally in line with contemporary expectation and serve to heighten the pathos of his death. At the same time, accompanying an innocence that leads directly to vulnerability, is the understated but clearly visible issue of economic pressure in both stories. Dynamics of wealth and poverty in each case justify the innocent's traffic with unsavory elements, resisted though these associations are by his family. In William's case, his apprenticeship as a tanner brings him into repeated contacts with Norwich Jews, who favor him and subsequently mark him out for his death of ritualized anti-Christian mockery. (The stench and proximity to dead flesh involved in the work of tanners adds to the general sense that William belongs to the working poor, much as Emanuel works in conditions his family finds undesirable.) William terminates these transactions with Jews under orders from his uncle Godwin and from one Wulward, with whom the boy resides in Norwich (I.iii). Emanuel, likewise, at least as reported a day or two later in the press coverage, shines shoes on Yonge Street despite familial resistance: the Globe and Mail, traditionally the most staid and ostensibly the most respectable of the Toronto dailies, offers the observation on August 2 that "His parents did not entirely approve, but peer pressure encouraged Manuel to spend his summer holidays shining shoes on Yonge Street" (York and Lipovenko). Emanuel's mother is quoted at the beginning of a Star article the next day as saying, "I didn't realize how bad a place it was. Close it down for all mothers to protect their sons"" (Dalby).

In William's story, but not in Emanuel's, we observe a direct confrontation between the boy's family and the stranger who lures him to his death. William is taken off by a man who claims to be in the employ of the archdeacon's cook. William's mother resists the man's requests and William's own entreaties - "Let me earn the 
money, let me earn the money," we might well imagine him saying at this point - but she subsequently capitulates, conquered if not convinced both by the boy's entreaties and by the three shillings the ensnarer pays to her (I.iv). William's aunt subsequently meets the ensnarer in William's company when they reach Norwich; she dispatches her daughter to follow them from afar. The daughter sees them turn into a Jew's house. By contrast, Emanuel's brother and friend last see him leave the restaurant where all three have met the ensnarer, after all three have hoped to get in on the lucrative prospect of a few hours' work that he offers.

Compensating for this gap in the Jaques narrative is the increasing emphasis on Emanuel's mother's altogether intelligible regrets. The August 3 Star article cited above reports, "'My children have been told not to go anywhere far from home', she said. 'I feel terrible. I made a mistake, a terrible mistake', she said quietly. She said her husband Valdemiro was literally 'sick with grief' in his bedroom" (Dalby).

The dynamics of familial grief are likewise bound up with the communal pity and rage that follow the discoveries of both murders. In both instances, the excessive quality of feminine reactions figures largely. Upon hearing of William's death, his aunt recalls a dream she had had the week before Palm Sunday, in which the Jews tore off her right leg. She then collapses in a swoon, from which she recovers only to fall into protracted, unrestrainable lamentations. William's mother weeps and wails in the streets like a mad woman, denouncing the guilt of the Jews in public places, until the populace at large begins to cry out unanimously that "the Jews ought to be utterly destroyed as constant enemies of the Christian name and the Christian religion" (I.xiv-xv).

A particularly striking image in this regard from the Jaques coverage is the photograph published by the Sun in its coverage of Emanuel's funeral (Cosway). The caption reads, "A cousin of Emanuel's, Dianna Correira, is carried from graveside after fainting." In the photograph, a young woman is held chest-high by a sober-faced young man in three-quarters view. She is wearing a dark dress; her head, shown in profile, hangs back limp from his arm, which supports her shoulders; his right hand curves over her breast just under her right arm. Her left shoulder is slightly higher, 


\section{2 / Townsend}

making of the modest neckline of her dress a dramatic $\mathrm{V}$ that focuses our attention back onto the grim expression of the dark, long-haired, photogenic man who carries her. The background is filled with outof-focus foliage and the faces of other mourners. Under an accompanying photo on the same page, we are told, "Weeping mother Maria Jaques is helped from the church by family friends." She is viewed from above, her darkened eyes visible under her veil; her left hand is grasped by a man in a plaid jacket. On her right, an older, soberly dressed woman in glasses holds her hand. Each of her supporters has an arm around her shoulder. The gaze of all three is directed at a single object (the coffin?) to their right.

The cries for vengeance against the Jews that are taken up at women's instigation by the people of Norwich are echoed in the protests and petitions organized before and after the Jaques funeral. A photo in the August 4 Globe and Mail, the day of the funeral and the day before its coverage, shows protesters from Regent Park, the public housing project where the Jaques family lived, carrying signs that read "Kill Sex Perverts. Jail's Too Good," and less prominently in the background, "Capital Punishment Again! Down with Body Rub Joints!" (Porambo, 4 Aug.). The next day, in the Globe's coverage of the funeral, columnist Dick Beddoes reports a petition being handed around the funeral at St. Agnes's Church by Austin Raymond Miller of the Regent Park Community Improvement Association. "The petition was headed STAMP OUT GAYS AND BODY RUBS and Miller said he had 1,000 names on it. 'I'll get more', he said, 'and send it to Mayor Crombie'."

Beddoes's same column is worth further attention. It contains an uncanny echo of the dream of William's aunt: "Lose a child you've loved and it's like amputating a limb," Beddoes observes with a level of journalistic detachment characteristic of much of the coverage. "You keep going, but there is less of you." Beddoes's column furthermore ends with one of the earliest, and probably the most explicit, assertions of Emanuel's canonization: "So young - 12. Saint Agnes was also young - 13 when she was murdered in Rome in 304 A.D. for rejecting a suitor. Martyrs in death before they knew very much about life." Ron Porambo's Globe coverage, carried as well by the Vancouver Sun on August 9, ended its account of the funeral with a roster of collapsing mourners 
including Emanuel's father, his sister, and finally his mother. Porambo concludes, "Then the funeral that had turned into a virtual public passion play was finally over and done with" (Porambo, 9 Aug.). These point-blank assertions of canonization in fact summed up the impulse toward redemptive teleology that had already been indulged in a statement by Alderman Joseph Piccininni in the August 2 Star that "Emanuel's death is a 'terrible price' to have to pay to show that the strip needs cleaning up" (McNenley and Barnes 3). Such impulses had also already informed suggestions by Premier William Davis, Ontario Attorney General Roy McMurtry, and Toronto Mayor David Crombie that Emanuel's death was providing the impetus to deal with the long-standing problem of the Yonge Street strip ("Boy's death prompts government action"; "Toronto boy homosexual orgy victim").

Finally, all coverage of the Jaques murder and trial, virtually without exception, places one man first among the four perpetrators - Saul David Betesh. Betesh was in fact the man who went to the police and shortly thereafter confessed to the murder. He is also the only one among them whose given names distinctly suggest the possibility that he is a Jew, and whose surname sounds distinctly other than Anglo-Germanic. ${ }^{8}$

What to make of these and other narrative parallels between Thomas of Monmouth's text and the Jaques coverage? How conscious can such correspondences have been? Was the Jaques coverage in fact shaped by the broadly diffuse intertextual valences of the blood libel? If it was, did the coverage itself contrive such correspondences, or were the behaviors of the principals themselves shaped in real life by those intertexts? (As a specific example, did Ron Porambo gratuitously construct the funeral as a "virtual public passion play," or was it so lived by those who attended - Emanuel's photogenically fainting cousin and the rest of his family, the Toronto Portuguese community, Auxiliary Bishop Aloysius Ambrozic [now, incidentally, Cardinal Archbishop of Toronto], whom Dick Beddoes

${ }^{8}$ Betesh was the adopted son of Lillian and James Betesh of Toronto. "The Beteshes ... at the time ran a highly successful linen-importing business ... When a physician they knew and trusted approached them with a Jewish male child who had, he said, a very healthy background, they didn't hesitate [to adopt the child]" (Williams). 


\section{4 / Townsend}

quotes praying over the body?) And if one can make a case for the construction of Emanuel as a blood libel saint, can one go even further and establish specific intentional parallels with the life of William? The answer to this latter question is far more likely to be negative - though William's biography is the source of all later blood libel narratives, it exists in only one copy: the breadth of its influence is itself a testimony to the power of texts to proliferate beyond their ostensible boundaries into their cultures at large (Langmuir 1984; Dundes; Hsia). But even so, I do find interesting parallels not only in the narrative substance of the William and Emanuel stories, but in what I can only call the rhetorical pragmatics of the gaze in the two texts. Here I shift to engage principally the second of my inquiry's two movements, the rhetorical 'how' and 'why' of the texts.

I have already touched on one example of these pragmatics, the narrative importance of women's grief in the two accounts. Thomas of Monmouth is particularly striking in this regard. He describes the feminine weakness of William's mother and aunt in terms that the conventions of monastic antifeminism would normally lead us to take as straightforwardly repudiative. In fact, we might be somewhat surprised, coming to the end of his account of William's mother's very publicly displayed grief, that the author is not preparing us for a final comment of censure upon such excesses. Instead, the rage against the Jews incited by her intuitive accusations becomes the horizon of naturalized expectation: it pervades the entire account of how the Jews escaped with relative impunity from the consequences of their crime. Thomas, in other words, maintains the disembodied distance of his own gaze from the feminized excess of mourning. Yet at the same time he incorporates the energy of that irrational and feminized surfeit of emotion into the anti-Semitic ideological apparatus he constructs. ${ }^{9}$ No ordinary practitioner of

${ }^{9}$ I use the term anti-Semitism here, despite the historical gap between the medieval blood libel and the modern secular anti-Semitism of the nineteenth and twentieth centuries, as Langmuir has defined it, as a scapegoating of Jews to compensate for the intolerable contradictions in a dominant belief system (Langmuir 1990, esp. ch. 14).

My understanding of ideology draws on current appropriations and critiques of Althusser's model as outlined in "Ideology and Ideological State Apparatuses," notably those by Silverman and Sinfeld. Silverman assimilates Althusser's model to post-Lacanian 
misogyny, Thomas manages both to objectify women as hysterics and to appropriate that hysteria into his own ostensibly genderneutral worldview.

The gaze of the Jaques coverage deploys its representations of grief according to analogous patterns. The familial sorrow and anger described by Dick Beddoes and Ron Porambo is the pathetic object of journalistic scrutiny. Representations of the behavior of an enraged community are likewise held at writerly distance. In a demonstration by 10,000 to 15,000 people covered in the Star on August 9, reportage takes the homophobia of the crowd as its object without absorbing that homophobia directly into the writerly voice. Victoria Stevens's article quotes, among others, a woman who demands, "Are the queers and prostitutes more important than these people? Are the perverts running Yonge St.?" But precisely the same sentiments emerge naturalized as they spread from news items to the editorial columns and investigative reporting of all three Toronto dailies. Claire Hoy's Sun column of August 10 was particularly noteworthy for its homophobic virulence, as would be his later pieces in the ensuing months, but the two more comfortably middle-brow dailies voiced similar sentiments, albeit in more moderate language - sentiments Upper Canadian respectability might view as more foreign if displayed by fainting, shouting Portuguese mourners or protesters. In the Star on August 5, Dennis Braithwaite delivered a lengthy jeremiad, justifying his remarks as a response to an editorial published in the journal Content. As a furious Braithwaite summarized, "what is agitating the editor of Content, and what he devotes most of the magazine's limited space to, is an outraged attack on Toronto newspapers for their alleged denial of the rights of homosexuals. Virtue itself of vice must pardon beg." Braithwaite goes on to praise Anita Bryant for her crusade against gay rights: "Anita thought she had God on her side, forgetting that liberals long ago buried God and dethroned His teachings with a simple dictum:

feminist conceptions of the constitution of the subject. Sinfeld, following Raymond Williams over Althusser, is concerned to allow for a literary reading practice that both critiques the ideological imbrication of literature and allows for the possibility of resistant readings: such readings generate potentially counterhegemonic discourses out of the ruptures and gaps in the text's ideological surface. 


\section{6 / Townsend}

Every evil to excess." A somewhat more restrained but still clearly exasperated Scott Young began an editorial in the Globe on August 8 by reporting a conversation which "tacked around from consideration of last Monday's horror, the shoeshine boy murder, to distantly related subjects - such as whether decloseted gays (publicly declared homosexuals) should be allowed to teach school." $\mathrm{He}$ concluded, "The gays should tell the nuts among them - the ones who want to teach their branchline sex to children or youths - to shut up. They will never get the human rights they do deserve, if they insist on the one about taking it into the schools like a bunch of gay Billy Grahams."

It is the comfortable liberalism of Young's piece that in fact strikes me as in some sense closest to the rhetorical double play of Thomas's deployment of reported hysteria. Young casts himself as the exasperated holder of the middle ground, graciously conceding the eventual appropriateness of gay rights, while deferring any positive move toward the justice of immediate enfranchisement. His deferral of justice is implicitly rationalized on the grounds of precisely those connections to Emanuel's murder which he superficially claims are of the most distant sort: it would be immoderate, after all, to ban discrimination in the face of the level of furor surrounding the murder, particularly since militant homosexuals have no better sense than to rub salt into the social wound.

The gaze that operates in the Jaques coverage and in William's biography is most powerfully focused, perhaps, in the central events of the narratives that I leapt over in my comparative reading. I need to backtrack to the accounts of the murders themselves.

William is lodged comfortably with the Jews for a day after his arrival in their company. The next day he is bound and tortured with a teazle placed in his mouth and a knotted cord wrapped around his head and neck. Later his head is shaved and punctured with numerous thorns. Then the Jews crucify him in a peculiarly unstraightforward fashion. This they do, Thomas of Monmouth tells us, in order to leave marks on the body that would point to Christians rather than Jews as the perpetrators. Finally, a deep wound to his heart from the left side kills him. His murderers pour 
boiling water over the body to cleanse and close the wounds. The Jews decide that disposing of the body near their own lodgings is dangerous and agree to carry him outside the city to Thorpe Wood. En route, they meet one Aelward Ded, whose suspicions are aroused and who, upon examining the bag they carry over one of their horses, discovers that it contains a human body. The Jews flee into the wood, and Aelward returns home, saying nothing due to the injunctions of the Sheriff, who silences him in order to protect the Jews. (Only on his deathbed, five years later, will he reveal that he had encountered the murderers as they were transporting the little saint's body.) By a complex series of miraculously aided discoveries and rediscoveries, burials and exhumations, William is recovered and a month after his death translated to the monks' cemetery at the cathedral.

For the full details of Emanuel's death, we have to leap from the initial coverage of the murder investigation in August 1977 to the coverage of the trial of Saul David Betesh, Robert Wayne Kribs, Josef Woods, and Werner Gruener in February 1978. Emanuel is taken to an apartment above a body rub parlor. There his ensnarer Betesh and the other three take photographs of Emanuel for about an hour. At first the boy is clothed. He is persuaded gradually to remove his clothing. The men then tell him they want sexually explicit "action shots." According to the testimony reported in some of the accounts (O'Hara), Emanuel is at first reluctant but cooperates for a while after being offered an extra $\$ 20$. (In most repetitions of the testimony this last detail is omitted.) Later the boy is repeatedly raped, in an orgy that lasts about twelve hours. The men decide that it is impossible to let the boy go and the decision is made to kill him. Betesh tries for several minutes to strangle him with a length of plastic stretch cord. Woods then suggests he place a pillow over his face so that Betesh doesn't have to look at him. Finally, Betesh and Kribs drown Emanuel in a sink. The murderers go out to purchase a shovel and bury the boy, but the ground behind the building is too hard to dig and the corpse is left in a garbage bag on the roof. Several days later, Betesh goes to the police with a story that at first suggests his own innocence. In the course of the interrogation, however, he soon confesses his central role in the murder.

What distinguishes the life of William of Norwich from 


\section{8 / Townsend}

most later blood libel accounts is the graphic detail to which the reader is subjected. We do not merely learn that the boy is murdered. We are privy to every detail, with a gruesomeness that puts off a great many modern readers who can by contrast read Chaucer's Prioress's Tale with relatively unruffled sensibilities. And we are privy to the sight of the murder not only in the extended chapter of Book 1 which describes it, but again in its rehearsal in Book 2, where Thomas obsessively accumulates proofs of the guilt of the Jews. Most spectacularly, we are told that a Christian woman serving the Jews beheld through a half-closed door the body of William strung up between beams in the room where he died; but she dared not report the sight to anyone (II.ix). The repetitive detail with which William's ordeal is described is recapitulated, as by a kind of extended montage, in the proofs of his martyrdom in Book 2 , and less palpably by memorial association in the repeated translations with which the body is brought out into the sight of men, four times in a decade.

The Jaques coverage is even more obsessive in its repetition of the gory details, both after the murder and during the trial the next winter. One might well expect this, given the commercial exigencies of journalism. I am nevertheless inclined to see the horrified fascination by which the Jaques coverage binds its reader to the text as deploying the abject pleasures of its gaze more insidiously than, say, the coverage of the Jeffrey Dahmer murders. ${ }^{10}$ The journalistic rehearsal of Emanuel's multiple rape, his botched strangulation and eventual drowning in a sink are like the "money shots" of film and video pornography, repeated from different angles, sometimes at real speed, sometimes in slow motion. As with pornography, what drives the viewer's fascination is the fact that the visual sequence somehow stands in for an unconscious but altogether crucial narrative pattern.

I propose that the urgency driving these representations is the ability of both Thomas's text and the Jaques coverage to stand as "faultline narratives," to use Alan Sinfeld's term - stories that can

${ }^{10}$ Jeffrey Dahmer was the Milwaukee man charged and convicted in 1992 for the killing and mutilation of seventeen young - mainly Asian and African-American - men. 
elide the contradictions in the cultural dispositions they purport to represent (3-5). Here, finally, I focus more on the 'why' than on the 'what' and 'how' of comparative rhetoric. As to the ideological contradictions that made the blood libel legends culturally useful in the high and late Middle Ages, I find useful the work of Kathleen Biddick and, once again, of Gavin Langmuir.

Biddick has traced some of the cultural predicaments at the heart of medieval Christian piety that may have displaced themselves into accusations of ritual murder against the Jews. Specifically, she suggests that the central importance of the Eucharist for medieval Christendom, and consequent upon that importance, the affective pieties of medieval women around the consumption and refusal of food, and around Christ's body and blood as food, dangerously juxtaposed the normative body with the excessive, in a way that threatened to break down the constitutive distinctions between Self and Other upon which the culture relied. As she puts it:

The Eucharist was good to think with, and it guaranteed the symbolic order of medieval Europe. It was both a "classical" body in the Bakhtinian sense, elevated, static, and monumental, and a "grotesque" body, broken, bleeding, excessive, maternal, paternal, a body that upset any fixed gender binary, a fluid body that troubled any container. It was a body that was distributed across different - and noncommensurate - textual, material, and visual realms. Christians fantasized intensely both the pollution and the purification of the Eucharist because of its ambivalent position as a border phenomenon. (153)

Biddick argues that the desecration of the bodies of Christian children represented in blood libel narratives constitutes an abjection of precisely those cultural predicaments created by the dominant discourses on the body of Christ in iconography, sacrament, and affective piety. She adduces in support of her argument the fact that noteworthy excrescences of Eucharistic piety frequently cropped up in the same times and places as blood libel accusations and rumors of Jewish desecrations of the Host (147-52).

Langmuir (1990) also addresses the kinds of pressures that lead people to adopt irrational hatred of the other in their midst as 


\section{0 / Townsend}

an alleviation of unbearable tension, but in contrast with Biddick's work, his argument proceeds in broader categories of the phenomenology of religion. Langmuir is at pains to establish a taxonomy for the representation of Jewish abjection. He argues for a threefold distinction between confessional opposition to Jewish beliefs, acceptance of negative representations of Jewish practice and identity due to inadequate empirical data, and irrational hostility in discourse and practice as a defence against rational objections to a belief system (or dominant cultural praxis) that one hypothetically could entertain but instead represses: "It can be argued that antiJudaism is a nonrational reaction to overcome nonrational doubts, while antisemitism is an irrational reaction to repressed rational doubts" (276). By a different path, Langmuir arrives at territory also explored by Biddick:

"The Jews" had become the great symbol of hidden menaces of all kinds within Christendom. In a rapidly changing Europe suffering from economic depression, social discontent, ecclesiastical divisions, bubonic plague, and endemic and devastating wars, many Europeans were prey to lurking doubts that sapped their self-confidence. They struggled to repress them but remained anxious, and many gave expression to their unease by attributing to Jews evil characteristics that made the goodness of Christians obvious by contrast and attributed their problems to an external source. (303)

As Langmuir suggests, the deployments of the blood libel from the twelfth to the twentieth centuries have embraced and attempted to contain a wide range of tensions. What Langmuir says of the need to expel doubts that might well occur about the cultural and economic dynamics of a society can serve as a starting point for comparing the cultural logic of the Norwich and Toronto narratives.

Among the pressing realities that the canonization of Emanuel Jaques elided was the economic deterioration of downtown Yonge Street in the heart of Toronto during the 1970s. The district had earlier functioned as a viable commercial neighborhood of local businesses selling a range of ordinary wares and servicing residential streets not far distant. Yvonne Chi-Ying $\mathrm{Ng}$ has documented the pressures placed on this local community. Yonge Street's emergence 
as the sex strip decried in the Jaques coverage had been proceeding for some years. Chief among the economic pressures that destroyed the viability of the street's earlier culture was the speculative rise in land values and rents from 1972 through 1974, as land parcels were assembled for the construction of a hulking shopping mall, the Eaton Centre, in the midst of the city (77-78).

For all the representations of Emanuel's loving family, of the cohesive working-class multiculturalism of his neighborhood, and of the wider but close-knit Portuguese community of Toronto, all those social configurations stood in jeopardy, as did the economic base on which 1970s Toronto had relied. At the same time, Emanuel's work as a shoeshine boy was, ironically, itself an index of the economic shifts that the cooption of the neighborhood for large-scale economic development had effected. He was himself one of those marginalized denizens of the street whose presence representatives of 'respectable' businesses in the area found objectionable. Ng's study traces the deployment of the Jaques coverage as a mechanism to produce public consent in support of a cleanup campaign that such figures, supported by the mayor of Toronto, had periodically advocated for several years.

If homosexual murderers of little boys, and by synecdochic extension all queers, became a widely adopted object of enraged denunciation in late-1970s Toronto, the dynamics of that hatred were surely various. But the Eaton Centre stood - stands - as a palpable coordinate of the social pressures that energized a significant share of that hatred. ${ }^{11}$ With that, I come full circle to the shamelessly personal set of associations with which I began, by connecting the landscape of downtown Toronto with that of twelfthcentury Norwich. The Norwich Jewry lay in the so-called New Burg, the twelfth-century settlement beyond the Norman castle at the southwest limit of the original Saxon town (Jessop and James, xlvxlix). Norwich Castle thus stood in the midst of a vastly transformed

${ }^{11}$ The contrast between the Eaton Centre and its surrounding streetscape, incidentally, has not diminished in the past two decades. Complaints about the seediness of the street continue, and a redevelopment project currently underway aims to create a more open (and sanitized) space - dubbed Dundas Square - more or less exactly on the site of the Jaques murder. 


\section{2 / Townsend}

and bustling twelfth-century city, perhaps the most palpable coordinate of the pressures that shaped life in that economically and culturally tumultuous time. Anti-Semitism offered Thomas's contemporary readers a way to expel a plethora of intolerable contradictions in their lives. In the twelfth as in the twentieth century, hatred, oppression, and murder were part of the practice of everyday life. But against the vagaries of texts and their uses, some monuments to power stand as givens above our lives, mute and guiltless, beyond the rage of those who read the world as its text is transmitted to them. ${ }^{12}$

\section{Works Cited}

Beddoes, Dick. "In Sorrow and Anger." Toronto Globe and Mail 5 Aug. 1977: 8.

Biddick, Kathleen. "Genders, Bodies, Borders: Technologies of the Visible." The Shock of Medievalism. Durham: Duke University Press, 1998. 135-62. Reprinted from Speculum 68 (1993): 389-418.

Boswell, John. Christianity, Social Tolerance, and Homosexuality: Gay People in Western Europe from the Beginning of the Christian Era to the Fourteenth Century. Chicago: University of Chicago Press, 1980.

"Boy's Death Prompts Government Action." Montreal Star 3 Aug. 1977: A2.

Braithwaite, Dennis. "Was Puritan Repression Really so Bad?" Toronto Star 5 Aug. 1977: E5.

Bullock, Helen, Paul Dalby, and Dave Norris. "Emanuel's Trust Led to his Death Neighbors Say." Toronto Star 2 Aug. 1977: 2. Cosway, John. "A Farewell to Slain Boy." Photos by Jac Holland. Toronto Sun 5 Aug. 1977: 32.

Dalby, Paul. "Rip Down 'Evil' Yonge Sin Strip Boy's Mom Says.”

12 Robin Metcalfe's play "The Civilization of a Shoeshine Boy" treats the connections between the Jaques murder and the pressures of urban redevelopment. It was produced by Buddies in Bad Times Theatre in Toronto in June of 1993. It remains unpublished 
Blood Libel / 23

Toronto Star 3 Aug. 1977: 1.

Davidson, True. "Guy-wires." Toronto Sun 11 Aug. 1977: n pag.

Dundes, Alan, ed. The Blood Libel Legend: A Casebook in Anti-

Semitic Folklore. Madison: University of Wisconsin Press, 1991.

Grass, Jennifer. "“Close the Trash' on Yonge Strip Woman, 74, Urges." Toronto Star 2 Aug. 1977: 2.

Hamburg, Harvey. "Anita Takes Miami; Gays Fight On." The Body Politic 35 (July/Aug. 1977): 1 \& 12.

Hannon, Gerald. "Taking it to the Streets." The Body Politic 71 (Mar. 1981): 9, 12, \& 16.

Hsia, R. Po-Chia. The Myth of Ritual Murder: Jews and Magic in Reformation Germany. New Haven: Yale University Press, 1988.

Hoy, Claire. "Gay Whining Falls on Deaf Ears." Toronto Sun 10 Aug. 1977: 16.

Jessop, Augustus and M. R. James, eds. The Life and Miracles of St. William of Norwich. Cambridge: Cambridge University Press, 1896.

Jonas, George. “Operation Bathhouse.” Toronto Life May 1981: 35. Langmuir, Gavin. "Thomas of Monmouth: Detector of Ritual Murder." Speculum 59 (1984): 820-46.

- History, Religion, and Antisemitism. Berkeley: University of California Press, 1990.

McNenley, Pat and Alan Barnes. "“Terrible Tragedy', Davis Says." Toronto Star 2 Aug. 1977: 1\& 3.

Mulgrew, Ian. "1,500 Demonstrators in March to Protest Police Raids on Baths." Globe and Mail 7 Feb. 1981, Toronto ed.: 1; "Homosexuals, Lawyers Claiming Harassment over Bathhouse Raids." British Columbia ed.: 2.

$\mathrm{Ng}$, Yvonne Chi-Ying. "Ideology, Media, and Moral Panics: An Analysis of the Jaques Murder." M.A. Thesis. University of Toronto (Centre of Criminology), 1981.

"Not so 'Gay'." Toronto Sun 11 Aug. 1977: 10.

O'Hara, Jane. "Boy Ravaged for 2 Hours: 'We Couldn't Let Him Go'." Toronto Sun 14 Feb. 1978: 3.

Porambo, Ron. "The Neighbours March for Manuel." Toronto Globe and Mail 4 Aug. 1977: 4. 
24 / Townsend

—. "The Day They Buried Emanuel." Vancouver Sun 9 Aug. 1977: 5.

Rayside, David. On the Fringe: Gays and Lesbians in Politics. Ithaca: Cornell University Press, 1998.

Ross, M. "Sacrificed on Altar of Civil Rights." Toronto Star 9 Aug. 1977: B5.

Scanlon, Kevin. "Portraits - TRAGEDY ... AND SLEAZE." Toronto Sun 2 Aug. 1977: 34-35.

Shulman, Morton. "Never One to Stay out of a Fight." Toronto Sun 9 Aug. 1977: 11.

Silverman, Kaja. Male Subjectivity at the Margins. New York: Routledge, 1992.

Sinfeld, Alan. Cultural Politics - Queer Reading. Philadelphia: University of Pennsylvania Press, 1994.

Stevens, Victoria. "Angry Crowd Seeks Revenge for Emanuel." Toronto Star 9 Aug. 1977: 1.

Thomas, Gwyn (Jocko). "Shoeshine Boy Found Slain Suspect Held." Toronto Star 1 Aug. 1977: 1.

"Toronto Boy Homosexual Orgy Victim." The Province (Vancouver), 3 Aug. 1977: 5.

Williams, Stephen. "Sympathy for the Devil." Toronto Life Sept. 1979: 182-83.

Worthington, Peter. "Government Subsidized Trash." Toronto Sun 16 Aug. 1977: 11.

York, Marty and Dorothy Lipovenko. " 4 Men Charged with Murder After Body of Boy Discovered," Toronto Globe and Mail 2 Aug. 1977: 1.

Young, Scott. "Gays Should Learn When to Hush Up." Toronto Globe and Mail 8 Aug. 1977: 8. 